\title{
Coffee straw mineralization applied to the soil surface
}

\author{
Igor Rozado Bosa', Paola Alfonsa Vieira Lo Monaco', Ismail Ramalho Haddade', Henrique Teodoro Barth', \\ Gustavo Haddad Souza Vieira', Caroline Merlo Meneghelli²*, Sávio da Silva Berilli \\ ${ }^{1}$ Department of Plant Science, Federal Institute of Education, Science and Technology of Espírito Santo-campus Santa Teresa, Highway \\ ES-080, Km 93, s/n - São João de Petrópolis, 29660-000-Santa Teresa - ES, Brazil, ${ }^{2}$ Department of Plant Science, Federal University of \\ Viçosa, Peter Henry Rolfs Avenue, s/n - Campus Universitário, 36570-900-Viçosa-MG, Brazil, ${ }^{3}$ Department of Plant Science, Federal Institute \\ of Education, Science and Technology of Espírito Santo-campus Itapina, Highway BR-259, Km 70, s/n - 29709-910-Colatina - ES, Brazil
}

\section{A B S T R A C T}

The potential use of coffee straw (composed of outer skin, pulp and parchment) as fertilizer for agricultural crops implies the need to know the dynamics of their decomposition and release of the nutrients. This is to assist the farmers in the management of these residues, especially in the best time of its application in the soil. The aim of this work was to evaluate the dynamics of organic carbon and organic nitrogen during the coffee straw mineralization process, when applied superficially to a Dystrophic Red-Yellow Latosol (LVAd). The experiment was conducted in a completely randomized design with ten treatments, related to different post-disposal periods to the soil $(0,7,13,20,27,34,48,69,98,147$ days) and four replications. Soil samples were collected to quantify the easily oxidized organic carbon (OCeo) and organic nitrogen ( $\mathrm{ON}$ ) contents and their respective mineralized fractions. The evaluation of OCeo mineralization, being more stable and less sensitive to climatic variations, is the most appropriate parameter to estimate the mineralized fraction of the residue. The application of coffee straw in a LVAd during the month of August provides, after 147 days, mineralized fractions of $\mathrm{OCeo}$ and $\mathrm{ON}$ around $88 \%$ and $36 \%$, respectively, in the climatic conditions of the mountain region of Espírito Santo state, Brazil.

Keywords: Coffee straw; Decomposition dynamics; Fertilizing

\section{INTRODUCTION}

Coffee production is a major agricultural activity for the socioeconomic development of the Espírito Santo State. However, along with high productivity, Meneghelli et al. (2016) point out that coffee processing generates large amounts of fruit residues, such as straw, pulp and mucilage, as well as waste water, depending on the processing method adopted.

Among the residues of coffee processing, straw has been recycled by the producers to fertilize the coffee plantations, due to its high nutrient content, especially nitrogen and potassium, as verified by Assis et al. (2011) and Lo Monaco et al. (2013). However, farmers are unaware of the dynamics of this organic material in the soil or when the material becomes mineralized. This information is important so that fertilizer application to the crop can be planned in a way that can efficiently absorb the available nutrients, depending on the soil and climatic conditions of the region.
Agricultural waste recycling as nutrient source is an economical and environmentally viable alternative, when the doses applied are adequate to meet the crops needs (Matos, 2010). The potential use of these residues in crop fertilizer application implies the need to know the dynamics of decomposition and release of nutrients, with the aim to establish strategies that allow the synchronization of nutrient release with the times of greater demand for agricultural crops, while avoiding nutrient immobilization and/or rapid mineralization (PITTA et al., 2012).

According to Matos (2010), the use of organic residues in agriculture as fertilizers, besides providing the plants with macro and micronutrients, it also represents environmental protection and conservation of natural resources. Among other benefits, the correct disposal of organic residues in the soil improves the structure and stabilization of aggregates, increasing total porosity, ameliorating physical water-related conditions, boosting water retention capacity and complexation/chelation of toxic substances. On the other hand, if the amount of organic residues disposed

\footnotetext{
${ }^{*}$ Corresponding author:

Caroline Merlo Meneghelli, Department of Plant Science, Federal University of Viçosa, Peter Henry Rolfs Avenue, s/n - Campus

Universitário, 36570-900- Viçosa-MG, Brazil. E-mail: carol.merlo@hotmail.com
} 
is above the soil supporting capacity or the crops nutrient requirements, it can generate environmental problems such as nitrogen losses, increase in the population of pathogens and vectors and in the concentration of heavy metals, as well as soil salinization (Pereira et al., 2015).

Therefore, studies were carried out aiming to evaluate the mineralization and degradation of some residues in the soil (Pereira et al., 2015; Paula et al., 2013; Diniz et al., 2016), being the mineralized fraction an important variable to prescribe the doses or amounts of organic matter that should be used in the fertilization program (Paula, 2012). Obtaining this is, however, complex. Mineralization is influenced by large number of factors that influence the soil $\mathrm{C}$ and $\mathrm{N}$ dynamics, such as edaphic and climatic conditions, organic residue characteristics and disposal method (Paula et al., 2013).

Due to the lack of information on the mineralization dynamics of coffee straw in the soil, especially in the edaphic and climatic conditions of the Serrana region of Espírito Santo, this study becomes essential, since it enlighten about the use and correct time of application of this agricultural residue. Recycling organic residues eliminates the environmental impact of the wastes generated in the farms, once they are harnessed and disposed in the soil in a harmonic way with the environment. Also, it promotes a reduction in fertilization costs, benefiting the entire chain, from the producer to the consumer. Thus, the aim of this work was to evaluate the dynamics of organic carbon and nitrogen during the coffee straw mineralization process, when applied superficially to the soil.

\section{MATERIAL AND METHODS}

The experiment was carried out in a field condition, in a Dystrophic Red-Yellow Latosol, at the Federal Institute of Espírito Santo (FIES), Santa Teresa campus, in the municipality of Santa Teresa, Brazil, located at the following geographical coordinates: latitude $19^{\circ} 48^{\prime}$ South, longitude $40^{\circ} 40^{\prime}$ West and altitude of $130 \mathrm{~m}$. The annual average temperature is $24^{\circ} \mathrm{C}$ and the average rainfall ranges between 900 and $1200 \mathrm{~mm}$.

The residue from the drying coffee process was collected from a local agricultural property, located in the Municipality of Santa Teresa, Espírito Santo. The residues were used in the way they were collected, that is, without crushing or sieving.

The chemical and physico-chemical characterization of coffee straw was carried out at the Laboratory of Water Quality and Solid Residues of FIES - campus Santa
Teresa. The physical-chemical analysis consisted of the determination of the electrical conductivity (EC), by means of a bench conductivity meter. The chemical analysis consisted of the determination of $\mathrm{pH}$, by means of a bench top $\mathrm{pH}$ meter, and the quantification of easily oxidized organic carbon (OCeo), total organic carbon (TOC), total nitrogen $(\mathrm{TN})$, mineral nitrogen $(\mathrm{MN})$ and organic nitrogen $(\mathrm{ON})$ contents, and the $\mathrm{C} / \mathrm{N}$ ratio following the methodology described by Matos (2015). Table 1 shows the chemical and physical-chemical characteristics of the coffee straw used in the experiment.

The amount of organic residue applied to the soil was based on the amount of $\mathrm{N}$ required for a production of $50-70$ bags ha-1 of coffee grains, which is equivalent to $380 \mathrm{~kg}$ ha $^{-1}$ year $^{-1}$ of N, as recommended by Prezotti et al. (2007). The equivalent amounts were applied per area per year.

The experiment was conducted in a completely randomized design, with ten treatments and four replicates, with the treatments composed of the different post-conditioning periods of the residue in the PVC rings $(0,7,13,20,27$, 34, 48, 69, 98 and 147 days). The residues were applied manually.

The mineralization process was monitored by burying perforated PVC pipe rings with $20 \mathrm{~cm}$ in diameter and $5 \mathrm{~cm}$ high, to allow the free movement of solutes between the two media (Figs. 1 and 2).

\begin{tabular}{|c|c|c|c|c|c|c|c|}
\hline \multirow[t]{2}{*}{$\mathrm{pH}^{(\mathrm{a})}$} & EC & \multirow[t]{2}{*}{ OCeo } & TOC & TN & MN & ON & \multirow[t]{2}{*}{$\mathrm{C} / \mathrm{N}$} \\
\hline & dS $m^{-1}$ & & \multicolumn{3}{|c|}{$\%$} & & \\
\hline 5.1 & 3.66 & 37.52 & 48.77 & 1.26 & 0.17 & 1.09 & 38.70 \\
\hline
\end{tabular}

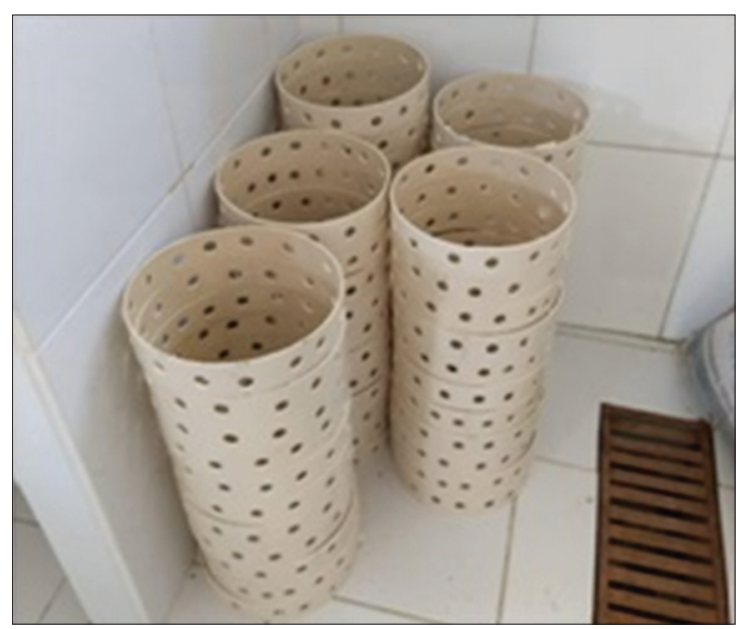

Fig 1. Perforated rings used to condition the coffee processing residue in the soil. 
The residue was applied on the soil surface and inside the rings. The rings were crimped in the ground and the soil inside it was removed to place the residues. Samples with approximately $100 \mathrm{~cm}^{3}$ of material were collected at 0,7 , 13, 20, 27. 34, 48, 69, 98, 147 days after the experiment was set up to analyze the concentration of OCeo and TN, inorganic nitrogen in the ammonium $\left(\mathrm{NH}_{4}^{+}\right)$and nitric $\left(\mathrm{NO}_{3}^{-}\right)$ forms, following the method described by Matos (2015). The concentration of organic nitrogen was obtained by discounting the concentration of mineral forms $\left(\mathrm{N}-\mathrm{NH}^{4+}\right.$ and $\mathrm{N}-\mathrm{NO}_{3}$ ) of the total $\mathrm{N}$ value determined at each sampling.

The OCeo and ON contents, obtained from 0 to 147 days, were used directly in Equation 1, to obtain the mineralized fractions observed (MfOCeo(ob) and $M f O N(o b))$, proposed by Paula et al. (2013). The percent values are given in mass by mass.

\section{$\operatorname{MfOCeo(ob)}=100$}

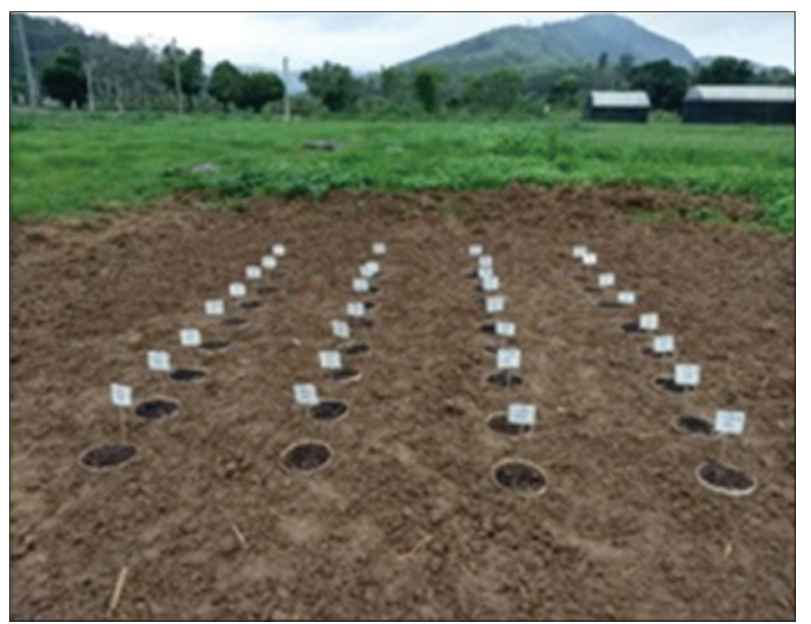

Fig 2. Detail of the crimping of the rings in the soil and the disposal of the residue on the surface of the soil.
Where:

OCeo(sr)in - is easily oxidized organic C in the soil/residue at the beginning of the sample incubation period $(\%)$;

$O C e o(s r)$ end - is easily oxidized organic C in the soil/residue at the end of the sample incubation period (\%);

OCeo(s)in - is easily oxidized organic C in the soil, at the beginning of the sample incubation period ( $\%)$;

And $O C e o(s) e n d-$ is easily oxidized organic C in the soil at the end of the sample incubation period ( $\%)$.

Concerning organic nitrogen (Equation 2):

$\operatorname{MfON}(o b)=100$

Where:

$\mathrm{ON}(\mathrm{s} r)$ in - is organic $\mathrm{N}$ in the soil/residue at the beginning of the sample incubation period $(\%)$;

$\mathrm{ON}(\mathrm{sr})$ end - is organic $\mathrm{N}$ in the soil/residue at the end of the sample incubation period $(\%)$;

$\mathrm{ON}(\mathrm{s}) \mathrm{in}$ - is organic $\mathrm{N}$ in the soil at the beginning of the sample incubation period (\%);

And $O N(s)$ end - is organic $\mathrm{N}$ in the soil at the end of the sample incubation period (\%).

Organic carbon OCeo(min) and organic nitrogen $O N($ min) contents, mineralized over time, were obtained by the differences between the contents on the day the residue was applied (Day zero) and those quantified on the next day.

Climatic data of rainfall and temperature were collected during the months of August 2018 to January 2019, at the Santa Teresa campus (FIES) weather station, to be used as auxiliary information in the discussion of the results. The data of air temperature and rainfall during the experimental period are presented in Figs. 3.

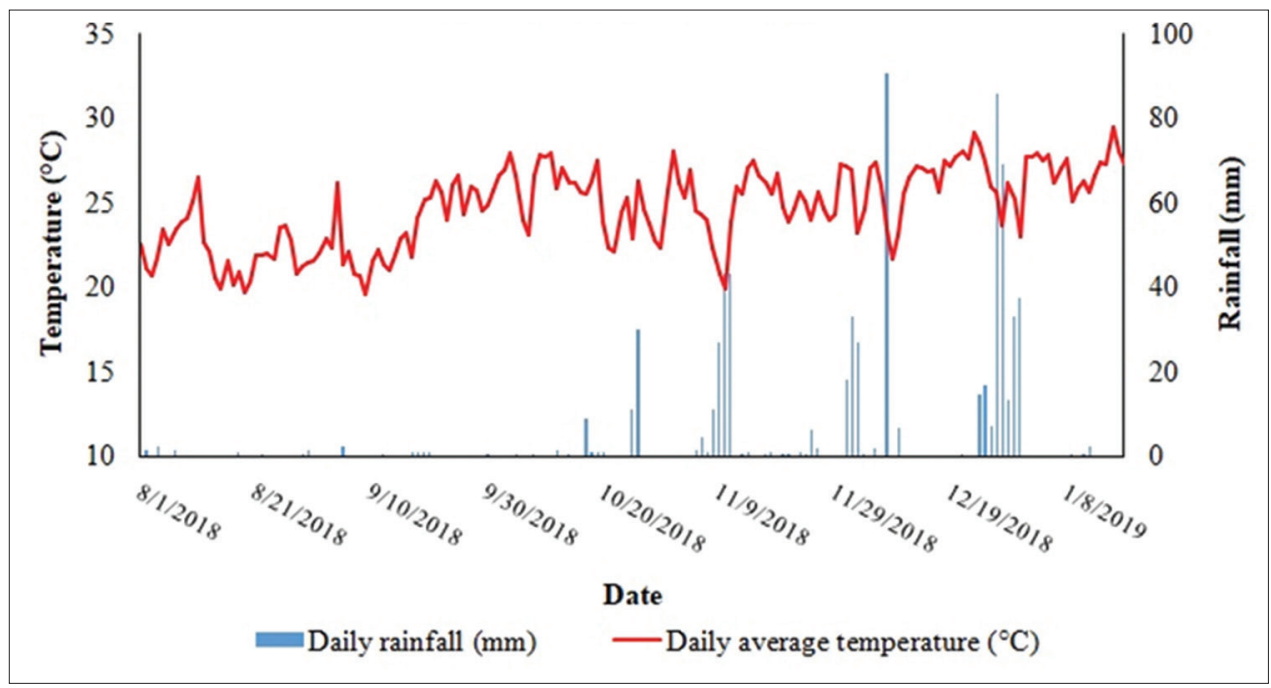

Fig 3. Temperature and rainfall data during the decomposition period of coffee straw superficially disposed in the soil. 
The data were submitted to the Levene (Homoscedasticity) and Shapiro-Wilk (Normality) tests, and analyzed according to CRD, with 10 treatments (referring to the post-conditioning of the residues in the rings) and four replicates, evaluated by analysis of linear regression (linear model), according to Equation 3:

$y_{i j}=m+I_{i}+e_{i j}$

Where:

$\mathrm{y}_{\mathrm{ij}}=$ observed value

$\mathrm{m}=$ general constant

$I_{i}=$ age effect

$\mathrm{e}_{\mathrm{ij}}=$ random error assumption NID.

The regression equations were used to describe the behavior of organic carbon and organic nitrogen, as well as their mineralized fractions, during the post-conditioning period in the soil. For all procedures an " $\alpha$ " of up to 0.01 was adopted.

\section{RESULTS AND DISCUSSION}

The organic carbon contents and mineralized organic carbon fractions, respectively, are shown in Table 2 and Figs. $4 \mathrm{a}$ and 4b, and, in Figs. 5a and 5b, the organic nitrogen contents (difference between total nitrogen and ammonium nitrogen) and the mineralized organic nitrogen fractions of the coffee straw, during stead of along.

According to the results presented in Fig. 4a, there is a decreasing linear behavior of the organic carbon content of the coffee straw, during the monitoring days, due to the mineralization process. Decrease in the organic carbon content during stead of along, as it is mainly due to the release of $\mathrm{CO}_{2}$, resulting from the respiration of the

\begin{tabular}{|c|c|c|c|c|c|c|}
\hline \multirow[t]{2}{*}{ Days } & OCeo & TN & MN & ON & MfOCeo & MfON \\
\hline & \multicolumn{6}{|c|}{$\%$} \\
\hline 0 & 37.52 & 1.26 & 0.17 & 1.09 & - & - \\
\hline 7 & 35.64 & 1.60 & 0.18 & 1.42 & 4.24 & -45.18 \\
\hline 13 & 34.42 & 1.38 & 0.13 & 1.24 & 7.77 & -28.62 \\
\hline 20 & 33.46 & 2.12 & 0.20 & 1.92 & 15.36 & -25.05 \\
\hline 27 & 33.20 & 1.36 & 0.17 & 1.19 & 17.32 & -20.52 \\
\hline 34 & 32.78 & 1.46 & 0.16 & 1.30 & 13.42 & -33.07 \\
\hline 48 & 32.04 & 1.36 & 0.22 & 1.14 & 15.19 & -11.93 \\
\hline 69 & 23.79 & 1.34 & 0.18 & 1.16 & 37.92 & -18.32 \\
\hline 98 & 22.19 & 0.64 & 0.15 & 0.48 & 42.62 & 53.21 \\
\hline 118 & 10.06 & 1.04 & 0.11 & 0.92 & 76.99 & 17.48 \\
\hline 147 & 3.04 & 1.01 & 0.19 & 0.82 & 93.33 & 24.71 \\
\hline
\end{tabular}

OCeo-easily oxidized organic carbon; TOC-total organic carbon; TN-otal nitrogen; $\mathrm{MN}$-mineral nitrogen; ON-organic nitrogen; MfOCeo-mineralized fraction of organic carbon; MfON-mineralized fraction of organic nitrogen microorganisms responsible for the transformation of organic matter (Kiehl, 2002).

Figure $4 \mathrm{~b}$ shows that the estimated mineralized fractions of organic carbon, at 30,60, 90, 120 and 150 days of monitoring, were $15.6 ; 33.9 ; 52 ; 70.3$ and $88 \%$, respectively.

Comparing these results with those obtained by other authors, although they used other organic residues, it is verified that the organic carbon mineralization process in the present work was slower. When studying the decomposition process of organic carbon and organic nitrogen in peach-palm residues applied superficially to the soil or incorporated, at field and laboratory conditions, Pereira et al. (2015), verified that the estimated mineralized fraction of OCeo was $50.98 \%$ after 28 days of incubation of the residue when it was applied on soil surface. Paula et al. (2013), when analyzing different methods of estimating the mineralized fractions of cattle, pig and poultry manure, as well as sewage sludge and urban waste compost, incorporated or disposed superficially on a Dystrophic Red-Yellow Latosol (LVAd), verified that the estimated OCeo mineralized fractions were, after 30 days of incubation of the residue, higher than $75.6 \%$, in the superficially disposed residues.

According to Figueiredo et al. (2012), several factors interfere in the decomposition and mineralization of organic residues, including the C:N ratio of the material, its physico-chemical and biological characteristics, as well as soil temperature and humidity.

The longer time required for the coffee straw organic carbon mineralization may be associated mainly with the climatic conditions that occurred during the monitoring period, especially in August and September. According to Fig. 3, it can be observed that during these months there was no rainfall, thus delaying the mineralization process. The characteristics of the residue may also have contributed to a longer mineralization time. According to Barcelos et al. (1997), besides having tannins and caffeine in its composition, coffee straw also has a high very lignified fiber content, which may have hampered the degradation process by the microorganisms.

As for organic nitrogen mineralization (Fig. 5a), there is also a decreasing linear trend, however, with a low coefficient of determination, due to the high instability of this variable, making it difficult to estimate the mineralized fraction (Fig. 5b). This fact was also verified by Pereira et al. (2015) and Paula et al. (2013), when studying the mineralization of several residues in the soil. Paula et al. (2013) concluded that the levels of inorganic nitrogen and, consequently, of organic nitrogen, are subject to the 


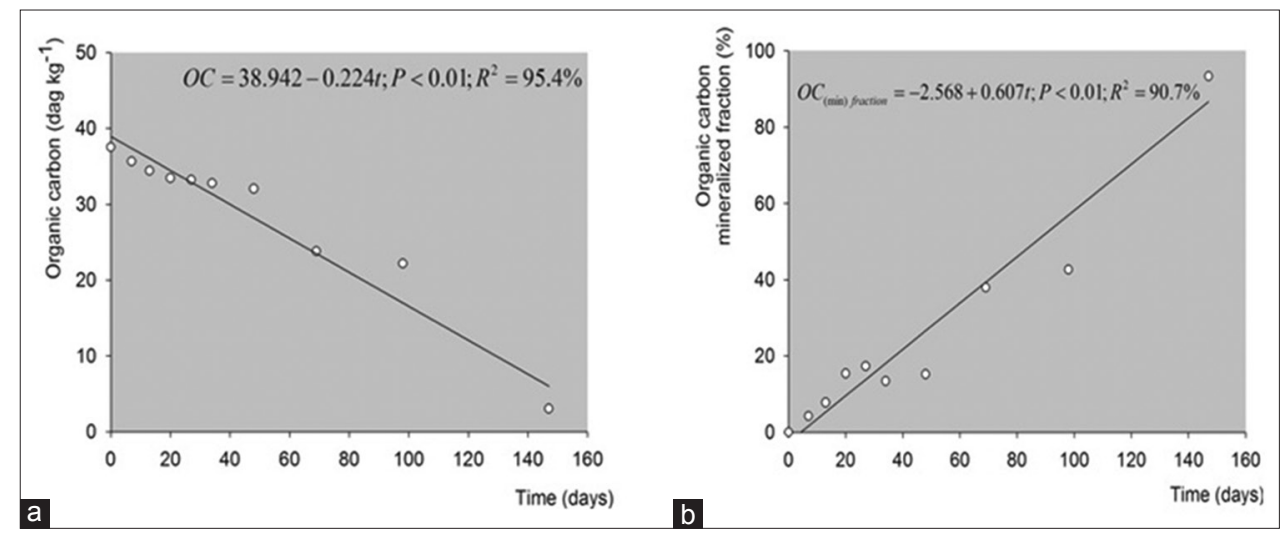

Fig 4. Organic carbon content (a) and mineralized organic carbon fractions (b) of coffee straw, along the degradation period in the soil.
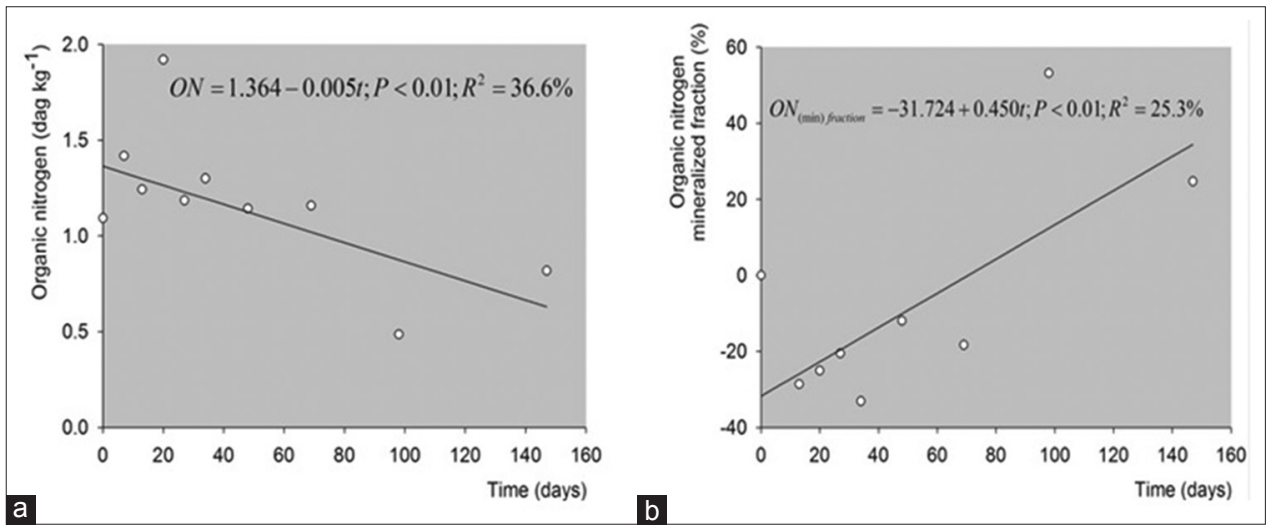

Fig 5. Organic nitrogen content (a) and mineralized organic nitrogen fractions (b) of coffee straw, along the degradation period in the soil.

strong influence of climatic variations and, for this reason, have generated unreliable estimates of the mineralized fraction of the organic residues studied, as occurred in the present study. Pereira et al. (2015) state that the use of OCeo as a reference for the evaluation of organic waste, is the most indicated.

Figure $5 \mathrm{~b}$ shows that the mineralized fraction of organic nitrogen became larger after 100 days, coinciding with the beginning of rainfall (Fig. 3). At the end of the monitoring period (150 days), the organic nitrogen mineralized fraction reached about $36 \%$.

Although coffee straw needs a longer time to be mineralized during the period studied (August to January), it is emphasized that this is the moment when the residue is generated, therefore, it needs to be managed at this occasion. If the farmer disposes of the residue in coffee plantations at the time it is generated, that is, around the month of August, nutrients such as nitrogen may be available in December and January, a period of greater nutritional demand for Conilon coffee.

Considering that the organic carbon is the most appropriate parameter to estimate coffee straw mineralization, it is assumed that, after 147 days, the nutrients are already available for coffee crop.

\section{CONCLUSION}

The evaluation of OCeo mineralization, being more stable and less sensitive to climatic variations, is the most appropriate parameter to estimate the mineralized fraction of the residue. The application of coffee straw in Dystrophic Red-Yellow Latosol during August provides, after 147 days, OCeo and ON mineralized fractions around $88 \%$ and $36 \%$, respectively, under the climatic conditions of the Espírito Santo Serrana region. This result becomes important once it allows a better fertilization program management, aiming to overlap the release of nutrients with the time of greatest nutritional demand for the crops.

\section{ACKNOWLEDGMENTS}

The authors thank the FAPES for financial support and the Federal Institute of Espírito Santo Research and Postgraduate Deanship Scientific Dissemination Program (PRODIF) for assistance in translating this manuscript. 


\section{Authors' contributions}

Authors 1, 2 and 4 elaborated the study and handled the writing of the manuscript. The author 3 performed the statistical analysis. Authors 5 and 6 performed the evaluations of the parameters analyzed in the study. The author 7 managed the bibliographic searches. All authors read and approved the final manuscript.

\section{REFERENCES}

Andrade, C. A., C. Oliveira and C. C. Cerri. 2006. Cinética de degradação da matéria orgânica de biossólidos após aplicação no solo e relação com a composição química inicial. Bragantina. 65: 659-668.

Assis, A. M., L. K. Unemoto, L. Y. Yamamoto, A. B. Lone, G. R. B. Souza, R. T. Faria, S. R. Roberto and L. S. A. Takahashi. 2011. Cultivo de orquídea em substratos à base de casca de café. Bragantia. 70: 544-549.

Barcelos, A. F., I. F. Andrade and I. M. E. Von Tiesenhausen. 1997. Aproveitamento da casca de café na alimentação de novilhos confinados-resultados do segundo ano. Rev. Bras. Zootec. 26: 1215-1221.

Diniz, I. C. C., A. T. Matos, A. C. Borges, J. M. L. Aquino and M. P. Matos. 2016. Degradation of sewage sludge compost disposed on the soil. Engenharia Agrícola. 36: 822-829.

Figueiredo, C. C., M. L. G. Ramos, C. M. M. Pimentel and A. M. D. Menezes. 2012. Mineralização de esterco de ovinos e sua influência na produção de alface. Hortic. Bras. 30: 175-179.
Kiehl, E. J. 2002. Manual de Compostagem: Maturação e Qualidade do Composto. $3^{\text {th }}$ ed. Agronômica Ceres Ltda, Piracicaba.

Lo Monaco, P. A. V., E. R. Paiva, A. T. Matos, G. C. Ferres and I. C. A. Ribeiro. 2013. Avaliação da relação $\mathrm{c} / \mathrm{n}$ e da qualidade do composto produzido em leiras de compostagem de carcaça e diferentes camas de criatório de frangos. Engenharia Agric. Viçosa. 21: 563-573.

Matos, A. T. 2010. Poluição Ambiental-impactos no Meio Físico. Imprensa Universitária, UFV, Viçosa.

Matos, A. T. 2015. Manual de Análise de Resíduos Sólidos e Águas Residuárias. $1^{\text {st }}$ ed. Editora UFV, Viçosa.

Meneghelli, C. M., P. A. V. Lo Monaco, I. R. Haddade, L. A. M. Meneghelli and M. R. Krause. 2016. Resíduo da secagem dos grãos de café como substrato alternativo em mudas de café Conilon. Coffee Sci. 11: 329-334.

Paula, J. R., A. T. Matos, M. P. Matos, M. S. Pereira and C. A. Andrade. 2013. Mineralização do carbono e nitrogênio de resíduos aplicados ao solo em campo. Rev. Bras. Ciên. Solo. 37: 1729-1741.

Pereira, M. S., A. T. Matos, A. C. Borges and M. F. Nunes. 2015 Mineralização do resíduo da pupunheira em condições de campo e laboratório. Engenharia Agrícola. 35: 918-930.

Pitta, C. S. R., P. F. Adami, A. Pelissari, T. S. Assmann, M. F. Franchin, L. C. Cassol and L. R. Sartor. 2012. Year-round poultry litter decomposition and N, P, K and Ca release. Rev. Bras. Ciên. Solo. 36: 1043-1053.

Prezotti, L. C., J. A. Gomes, G. Dadalto and J. A. Oliveira. 2007. Manual de Recomendação de Calagem e Adubação Para o Estado do Espírito Santo: $5^{a}$ aproximação. Biblioteca Rui Tendinha, Português. 